\title{
Selection for Nonadherent or Nonhydrophobic Mutants Co-selects for Nonspreading Mutants of Cytophaga johnsonae and Other Gliding Bacteria
}

\author{
By RICHARD H. WOLKIN AND JACK L. PATE* \\ Department of Bacteriology, University of Wisconsin, Madison, Wisconsin 53706, USA
}

(Received 7 August 1984; revised 28 November 1984)

Predictions based on a general model of surface components involved in gliding motility of Cytophaga johnsonae along with characteristics of previously isolated nonspreading mutants of $C$. johnsonae led us to suspect that isolation of such mutants could be accomplished by selecting for nonadherent or nonhydrophobic mutants. Accordingly, conditions were devised to select for mutants that failed to attach to cheesecloth suspended in growth media and for mutants that failed to adhere to $n$-hexadecane droplets. Populations of cells obtained from both selection procedures were screened for mutants producing nonspreading colonies. Both techniques resulted in enrichment for nonspreading mutants that were classified by previously established criteria as MNS (motile nonspreading), CNS (conditional nonspreading) or TNM (truly nonmotile). When assayed for adherence and hydrophobicity, all TNM mutants were nonadherent and nonhydrophobic, compared with wild-type cells. Most mutants of the other two classes were unchanged with respect to these properties. Results from subjecting cells of four other strains of gliding bacteria to selection by the same procedures indicate that the methods will be broadly applicable for isolating nonspreading mutants of gliding bacteria.

\section{INTRODUCTION}

Cells of Cytophaga johnsonae are characterized by their gliding movements and their ability to digest chitin (Stanier, 1946). A general model was proposed (Chang et al., 1984; Wolkin \& Pate, 1984 ) for surface components required for gliding motility of cells of $C$. johnsonae. The model was based on observations of latex microspheres moving on the surfaces of motile cells (Pate \& Chang, 1979), characteristics of nonspreading mutants (Chang et al., 1984), and effects of sugars on translocation of motile cells over agar gels (Wolkin \& Pate, 1984). According to the model, the operation of a system of moving components (machinery) in the cell envelope is responsible for keeping a slime moving over the cell surface. The nature of the machinery is still unknown, but suggestions based on observations of patterns of movement of attached latex microspheres include a system of rotary assemblies (Pate \& Chang, 1979), and components of the outer membrane moving along tracks in the cell envelope (Lapidus \& Berg, 1982).

Our interest in adhesion and hydrophobicity in $C$. johnsonae arose from predictions based on this general model and from some characteristics of previously isolated nonspreading mutants. Certain classes of nonspreading mutants of $C$. johnsonae were motile and moved latex microspheres but were unable to translocate over agar surfaces (Chang et al., 1984). We reasoned that some of these mutants might possess normal machinery but lack the slime or produce an altered slime, resulting in decreased adherence or hydrophobicity and allowing isolation of similar mutants from populations of cells selected for these characteristics. Another class of mutants, called truly nonmotile (TNM) mutants due to their failure to move or to move

Abbreviations: EC, enriched cytophaga medium; PB, phosphate buffer (5 mM, pH 7·1); AI, adhesion index; HI, hydrophobicity index; CNS, conditional nonspreading mutants; MNS, motile nonspreading mutants; TNM, truly nonmotile mutants. 
latex microspheres under any conditions tested, exhibited a peculiar pleiotropy: they were nonmotile, unable to digest chitin, and resistant to all phages that infect the parental strain (Chang et al., 1984). Furthermore, it was not possible to measure membrane potentials of cells of TNM mutants using lipophilic cations in a flow-dialysis system that allowed measurement of membrane potentials of wild-type cells (Chang, 1982). Growth characteristics of TNM mutants were similar to those of wild-type cells, which suggested they were not deficient in generating membrane potentials. From this it was reasoned that measurements of potentials using lipophilic cations failed because the surfaces of TNM mutants were more hydrophilic than those of wild-type cells. In addition, observations of cells attaching to surfaces of glass slides and coverslips led us to think that cells of TNM mutants were less adherent than those of wild-type cells. If these interpretations are correct, it should be possible to select various types of nonspreading mutants by selecting for nonadherent or nonhydrophobic mutants. Other methods for isolating nonspreading mutants of gliding bacteria have been reported (Burchard, 1970; Chang et al., 1984; Dayrell-Hart \& Burchard, 1979; Glaser \& Pate, 1973; Hodgkin \& Kaiser, 1977; MacRae \& McCurdy, 1976; Pate et al., 1979). We report here that nonspreading mutants can easily be isolated from unmutagenized populations of cells of $C$. johnsonae after selecting for nonadherent or nonhydrophobic cells, that the selection procedures appear to be widely applicable to gliding bacteria, and that assays for adherence and hydrophobicity are useful tools for characterizing nonspreading mutants.

\section{METHODS}

Bacterial strains. The phenotypes and origins of all strains of gliding bacteria characterized here are listed in Table 1. Flexibacter sp. strain FS-1 (Simon \& White, 1971) and Cytophaga sp. strain U67 (Henricksen, 1972) have not been characterized to species and are referred to throughout this paper simply as Flexibacter (FS-1) and Cytophaga (U67).

Phages. A total of 43 phages active against Cytophaga johnsonae strain UW 101 were used in this study. All were isolated by phage-enrichment procedures using $C$. johnsonae UW101 and propagated on that strain as described previously (Pate et al., 1979). Phages $\phi \mathrm{Cj1}, \phi \mathrm{Cj} 2, \phi \mathrm{Cj} 5, \phi \mathrm{Cj} 6, \phi \mathrm{Cj} 7, \phi \mathrm{Cj} 8, \phi \mathrm{Cj} 9, \phi \mathrm{Cj} 11, \phi \mathrm{Cj} 12, \phi \mathrm{Cj} 13, \phi \mathrm{Cj} 13 \mathrm{Ml}$, $\phi \mathrm{Cj} 14, \phi \mathrm{Cj} 15, \phi \mathrm{Cj} 16, \phi \mathrm{Cj} 20, \phi \mathrm{Cj} 21, \phi \mathrm{Cj} 22, \phi \mathrm{Cj} 23, \phi \mathrm{Cj} 24, \phi \operatorname{Cj} 25, \phi \mathrm{Cj} 26, \phi \operatorname{Cj} 27, \phi \mathrm{Cj} 28, \phi \mathrm{Cj} 29, \phi \operatorname{Cj} 30, \phi \operatorname{Cj} 31$, $\phi \mathrm{Cj} 32$ and $\phi \mathrm{Cj} 33$ were described by Pate et al. (1979); phages $\phi \mathrm{Cj} 40, \phi \mathrm{Cj} 41, \phi \mathrm{Cj} 42, \phi \mathrm{Cj} 43, \phi \mathrm{Cj} 44, \phi \mathrm{Cj} 45, \phi \mathrm{Cj} 46$, $\phi \mathrm{Cj} 47$ and $\phi \mathrm{Cj} 48$ were isolated and used for strain characterization previously (Chang et al., 1984); and phages $\phi \mathrm{Cj} 49, \phi \mathrm{Cj} 50, \phi \mathrm{Cj} 51, \phi \mathrm{Cj} 52, \phi \mathrm{Cj} 53$ and $\phi \mathrm{Cj} 54$ were recently isolated and have not been reported before.

Media. Flexibacter (FS-1), C. johnsonae, Flexibacter columnaris and Cytophaga (U67) were grown in enriched cytophaga (EC) medium (Glaser \& Pate, 1973) at $25^{\circ} \mathrm{C}$. Myxococcus xanthus was grown in CTT medium (Hodgkin \& Kaiser, 1977) at $30^{\circ} \mathrm{C}$. For solid media, agar was added to EC and CTT to final concentrations of 0.7 , 1.0 or $1.5 \%$. Chitin plates were prepared as described previously (Chang \& Pate, 1981) by adding chitin to a basal medium (SD) to a final concentration of $0.4 \%$. The SD medium contained: $0.5 \mathrm{~mm}-\mathrm{MgSO}_{4}, 0.2 \mathrm{~mm}-\mathrm{CaCl}_{2} .2 \mathrm{H}_{2} \mathrm{O}$, $0.05 \mathrm{~mm}-\mathrm{FeSO}_{4} .7 \mathrm{H}_{2} \mathrm{O}, 0.04 \mathrm{~mm}-\mathrm{EDTA}$, and $20 \mathrm{~mm}$-phosphate buffer (pH 7.25).

Selection and isolation of nonadherent mutants. (i) Use of cheesecloth and other materials. A modification of the procedure described by Umbreit \& Pate (1978) for the isolation of holdfast mutants of Asticcacaulis biprosthecum and Caulobacter crescentus was used. The selection procedure is based on the assumption that most cells in a population of wild-type cells will attach to cheesecloth (or other test materials) added to a liquid growth medium. As growth proceeds in such a culture, wild-type cells will adhere to the cheesecloth while any nonadherent mutants and their progeny will remain free in the broth. Successive cycles of transfer and growth of cells in a series of such cultures should result in populations of cells enriched for nonadherent mutants. If some or all nonadherent mutants are nonmotile, they should be easily identified by screening for nonspreading colonies produced on agar plates by cells of selected populations.

Selection flasks were prepared by adding $25 \mathrm{ml}$ of the appropriate nutrient broth (EC or CTT) to each of a series of $125 \mathrm{ml}$ Erlenmeyer flasks containing sterilized test material $(1.0 \mathrm{~g}$ chitin, $1.0 \mathrm{~g}$ glasswool, $1.0 \mathrm{~g}$ shredded tissue paper or $0.5 \mathrm{~g}$ shredded cheesecloth). To begin the selection, a flask containing a test material (selection flask) and a control flask with no test material were each inoculated with $1 \mathrm{ml}$ of an exponentially growing culture of the strain being selected. Flasks were incubated on a rotary shaker (175 r.p.m.) at the appropriate temperature until the optical density of the control culture reached at least $50 \mathrm{Klett}$ units, at which time a fresh selection flask and control flask were each inoculated with a $1 \mathrm{ml}$ sample from the liquid portion of the previous selection flask. Optical density was monitored in the control flask as an indication of growth in the selection flask because in most cases cells adhered to the test material so well that the liquid remained clear in the selection flasks throughout growth. Subsequent cycles of transfer and growth in a series of selection flasks containing the same test material as 
in the first selection flask were performed as just described. In general, after 1, 2, 4, 6, 8, 10,12, 16 and 20 such transfers, samples of the liquid portion of the selection flask were diluted to give rise to approximately 50 colonies per plate and plated in triplicate onto the appropriate medium solidified with agar $(1.5 \%)$.

(ii) Use of hexadecane. Adherence to hexadecane has been used to measure the relative hydrophobicity of different populations of bacteria and to select for hydrophilic mutants of various bacteria (Rosenberg et al., 1980; Rosenberg \& Rosenberg, 1981). The selection procedure is based on the assumption that cells with more hydrophobic surfaces will adhere to hexadecane to a greater extent than cells which are less hydrophobic. Therefore when an aqueous suspension of wild-type cells is overlaid with hexadecane, vortexed, and the two phases are allowed to separate, the population of cells remaining in the aqueous phase should be enriched in hydrophilic mutant cells. If some or all hydrophilic mutants are nonmotile, they should be easily identified by screening for nonspreading colonies produced on agar plates by cells of selected populations.

Wild-type cells were grown to late exponential phase in $25 \mathrm{ml}$ broth, harvested by centrifugation at $10000 \mathrm{~g}$ for $10 \mathrm{~min}$, washed once in a potassium phosphate buffer (PB; $\mathrm{pH} 7 \cdot 1,5 \mathrm{mM})$, and finally resuspended in the PB to an $\mathrm{OD}_{535}$ of 0.6 as determined using a Spectronic 20 spectrophotometer. A $9 \mathrm{ml}$ sample of this cell suspension was placed into a sterile acid-washed test tube, overlaid with $1 \mathrm{ml}$ filter-sterilized hexadecane, and vortexed for $1 \mathrm{~min}$. After allowing the aqueous and hexadecane layers to separate, the aqueous phase was removed and transferred to another sterile acid-washed test tube, overlaid with $1 \mathrm{ml}$ sterile hexadecane, vortexed for $1 \mathrm{~min}$ and the two phases were allowed to separate. This process was repeated through a series of 15 sterile acid-washed test tubes. The population of cells remaining in the aqueous phase after completion of a single extraction series is referred to as the $\mathrm{HI}$ population. A sample of the $\mathrm{Hl}$ population was serially diluted and plated onto the appropriate media solidified with agar (1.5\%). Typically, 20 plates per dilution were inoculated. In some experiments the $\mathrm{Hl}$ population of cells was subjected to a second selection cycle by transferring $0.5 \mathrm{ml}$ of the aqueous phase containing the $\mathrm{H} 1$ population into the appropriate fresh nutrient broth, incubating the culture at the appropriate temperature until late exponential phase, harvesting and washing the cells as just described and processing this cell suspension through another series of 15 test tubes containing hexadecane. The population of cells remaining in the aqueous phase after a second extraction series is referred to as the $\mathrm{H} 2$ population. When a third selection cycle was used, the population of cells remaining in the aqueous phase upon completion of a third extraction series is referred to as an $\mathrm{H} 3$ population. Cells of the $\mathrm{H} 2$ and $\mathrm{H} 3$ populations were serially diluted and plated as was just described for cells of the $\mathrm{Hl}$ population.

(iii) Identification of motility mutants. Selected populations of cells plated as just described were incubated at the appropriate temperature for $2 \mathrm{~d}$ [C. johnsonae, Cytophaga (U67), F. columnaris], $3 \mathrm{~d}$ [Flexibacter (FS-1)] or $4 \mathrm{~d}$ ( $M$. xanthus). The resulting colonies were screened for those which did not spread and the edges of nonspreading colonies were observed by phase-contrast microscopy. To ensure that each mutant isolated was the result of an independent mutation, each culture used in a selection procedure was initially inoculated with cells derived from a separate colony. Unless obvious differences in the edges of the colonies were observed by phase-contrast microscopy, only one nonspreading colony resulting from any given selection series was picked and isolated for further characterization.

Characterization of mutants. Recently, Chang et al. (1984) reported the isolation and characterization of a number of motility mutants of $C$. johnsonae. Based on colony spread on agar and motility of individual cells as observed in slide cultures and in wet mounts, three major categories of nonspreading mutants were defined: motile nonspreading (MNS) mutants whose cells are motile to varying degrees, but whose colonies fail to spread on agar gels under any conditions of incubation; conditional nonspreading (CNS) mutants with motile cells whose colonies require more moisture than those of wild-type cells in order to spread on agar gels; and truly nonmotile (TNM) mutants whose cells never move and whose colonies never spread under any condition tested. CNS mutants can be distinguished from MNS or TNM mutants on $1.5 \%$ agar gels incubated under ambient conditions by the morphologies of their respective colonies. Colonies of CNS mutants are compact and slightly raised with irregular edges. TNM and MNS mutants produce small, convex colonies with smooth edges. All 199 TNM mutants of $C$. johnsonae showed an unusual pleiotropy: they were resistant to all phages to which wild-type cells were sensitive and were unable to digest chitin (which is digested by wild-type cells). Mutants of the other two classes never exhibited this pleiotropy. In this study, nonspreading mutants derived from Cytophaga (U67), $F$. columnaris and Flexibacter (FS-1) were also classified as CNS, MNS or TNM on the basis of cell motility in wet mounts and colony spread on agar gels under various conditions of incubation (described below). Nonspreading mutants of $M$. xanthus were not classified as CNS, MNS or TNM because wild-type cells move so slowly that their movements in wet mounts cannot be observed. The following procedures were used where applicable to characterize nonspreading mutants.

(i) Cell motility in wet mounts. The ability of cells to move in wet mounts was determined using phase-contrast microscopy. For $C$. johnsonae, cells grown to late exponential phase in EC broth were used. For $F$. columnaris and

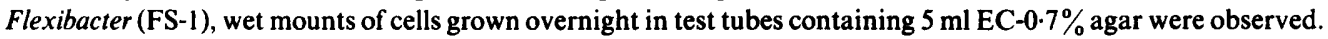
For Cytophaga (U67) and Flexibacter (FS-1), cells grown to early exponential phase in EC broth were observed. 
Table 1. Origins and phenotypes of bacterial strains

\begin{tabular}{|c|c|c|}
\hline \multirow{2}{*}{$\begin{array}{c}\text { Strain } \\
\text { C. johnsonae } \\
\text { UW101 }\end{array}$} & Phenotype* & Origin \\
\hline & & \\
\hline UW101 & W & Laboratory strain derived from ATCC 17061 \\
\hline $\begin{array}{l}\text { UW } 10233 \\
\text { UW10234 }\end{array}$ & $\left.\begin{array}{l}\text { TNM } \\
\text { TNM }\end{array}\right\}$ & Derived from UW $101 ; \phi \mathrm{Cj} 1$ selection (Chang et al., 1984) \\
\hline UW 10240 & TNM & Derived from UW $101 ; \phi \mathrm{Cj} 7$ selection (Chang et al., 1984) \\
\hline $\begin{array}{l}\text { UW10241 } \\
\text { UW10242 }\end{array}$ & $\left.\begin{array}{l}\text { TNM } \\
\text { TNM }\end{array}\right\}$ & Derived from UW101; $\phi \mathrm{Cj} 8$ selection (Chang et al., 1984 \\
\hline UW 10243 & MNS & Derived from UW101; $\phi$ Cj13 selection (Chang et al., 1984) \\
\hline UW 10248 & TNM & Derived from UW101; $\phi \mathrm{Cj} 25$ selection (Chang et al., 1984) \\
\hline $\begin{array}{l}\text { UW } 10252 \\
\text { UW } 10255\end{array}$ & $\left.\begin{array}{l}\text { TNM } \\
\text { TNM }\end{array}\right\}$ & Derived from UW101; $\phi \mathrm{Cj} 27$ selection (Chang et al., 1984) \\
\hline UW10261 & TNM & Derived from UW101; $\phi$ Cj30 selection (Chang et al., 1984) \\
\hline UW 10265 & TNM & Derived from UW10538; $\phi \mathrm{Cj} 31$ selection (Chang et al., 1984) \\
\hline $\begin{array}{l}\text { UW } 102146 \\
\text { UW } 102150\end{array}$ & TNM & \\
\hline $\begin{array}{l}\text { UW } 102150 \\
\text { UW } 102154\end{array}$ & $\begin{array}{l}\text { MNS } \\
\text { TNM }\end{array}$ & \\
\hline $\begin{array}{l}\text { UW } 102154 \\
\text { UW } 102155\end{array}$ & $\begin{array}{l}\text { TNM } \\
\text { TNM }\end{array}$ & Derived from UW 101 following NG mutagenesis (Chang et al., 1984) \\
\hline UW 102156 & TNM & \\
\hline UW1021 & MNS & \\
\hline UW 1022 & MNS & \\
\hline UW 1023 & MNS & \\
\hline UW1024 & CNS & \\
\hline UW 1025 & CNS & \\
\hline $\begin{array}{l}\text { UW } 1026 \\
\text { UW } 1027\end{array}$ & $\begin{array}{l}\text { CNS } \\
\text { CNS }\end{array}$ & Derived from UW101; selected for nonadherence to cheesecloth \\
\hline $\begin{array}{l}\text { UW } 1027 \\
\text { UW } 1028\end{array}$ & $\begin{array}{l}\text { CNS } \\
\text { CNS }\end{array}$ & \\
\hline $\begin{array}{l}\text { UW } 1028 \\
\text { UW } 1029\end{array}$ & TNM & \\
\hline UW 10210 & CNS & \\
\hline UW 10211 & CNS & \\
\hline UW 10212 & CNS & \\
\hline UW 10213 & CNS & \\
\hline UW10214 & CNS & \\
\hline UW 10215 & TNM & \\
\hline UW 10216 & CNS & \\
\hline UW 10217 & CNS & \\
\hline UW 10218 & TNM & Derived from UW101; selected for nonadherence to cheesecloth \\
\hline UW10219 & $\begin{array}{l}\text { CNS } \\
\text { CNS }\end{array}$ & \\
\hline $\begin{array}{l}\text { UW } 10220 \\
\text { UW } 10221\end{array}$ & $\begin{array}{l}\text { CNS } \\
\text { TNM }\end{array}$ & \\
\hline $\begin{array}{l}\text { UW10221 } \\
\text { UW10223 }\end{array}$ & TNM & \\
\hline UW 102298 & MNS & \\
\hline UW 102302 & TNM & \\
\hline UW 10222 & CNS & Derived from UW101; selected for nonadherence to chitin \\
\hline UW 10224 & MNS & Derived from UW101; selected for nonadherence to tissue paper \\
\hline UW10225 & TNM & Derived from UW 101 ; selected for nonadherence to glasswool \\
\hline UW10226 & CNS & \\
\hline UW 10227 & CNS & Derived from UW101; unselected nonspreading mutants \\
\hline UW 10228 & CNS & \\
\hline UW102299 & CNS & \\
\hline UW102300 & TNM & \\
\hline UW102301 & TNM & \\
\hline UW102343 & TNM & Derived from UW101; selected for nonadherence to hexadecane \\
\hline UW102344 & MNS & \\
\hline UW102345 & TNM & \\
\hline UW 102348 & TNM J & \\
\hline UW 102349 & Stre, TI & ved from UW102348; selected for resistance to streptomycin \\
\hline
\end{tabular}


Table 1. (continued)

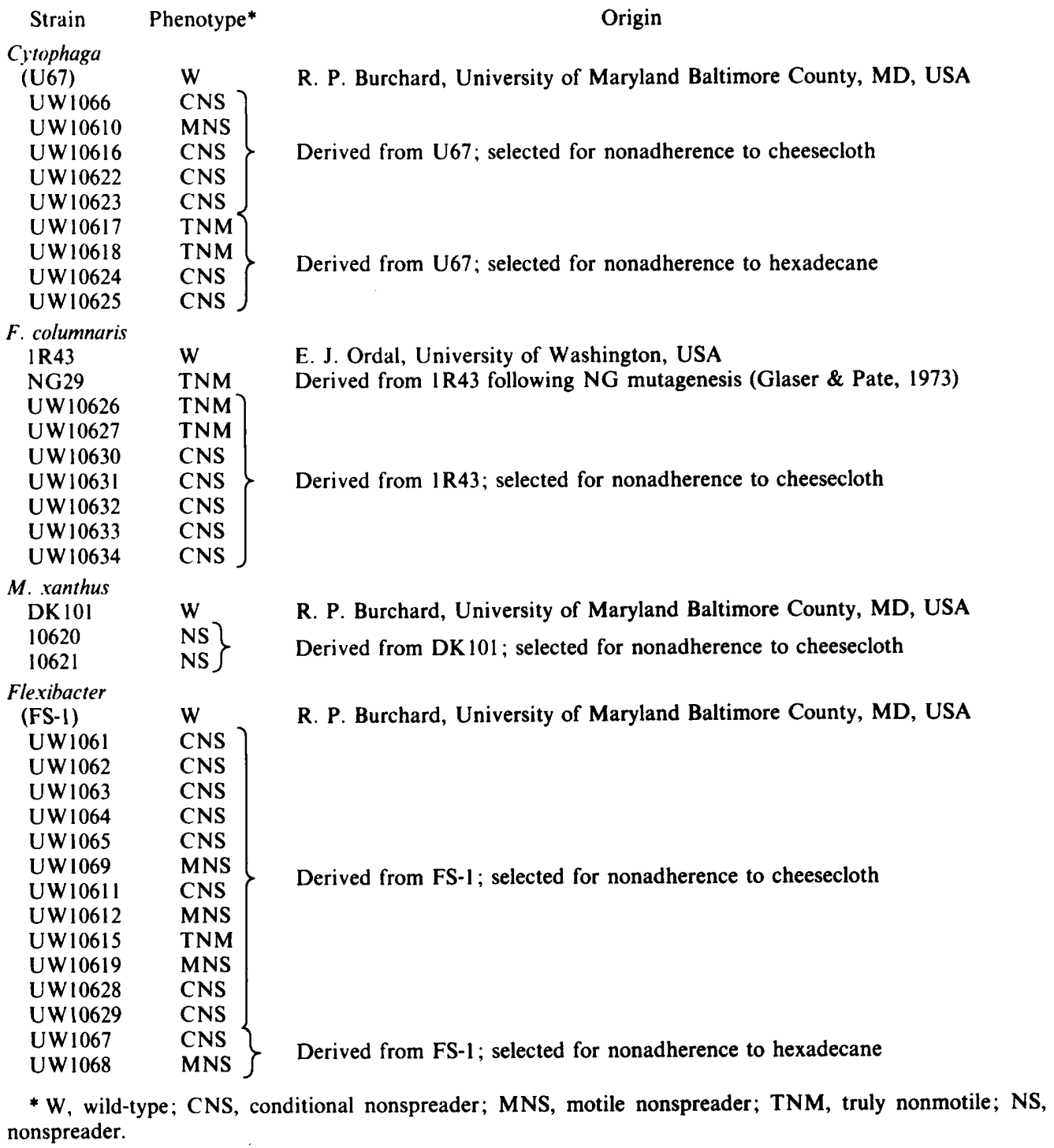

These conditions were chosen because wild-type cells of these bacteria are actively motile in wet mounts when grown as described.

(ii) Effect of agar concentration on colony spread. Cells grown to late exponential phase were inoculated using a multipoint inoculator onto EC or CTT plates containing $0.7,1.0$ or $1.5 \%$ agar and incubated for $24 \mathrm{~h}$ at the appropriate temperature. The ability of the cells to translocate and the patterns of colony spread were observed by phase-contrast microscopy.

(iii) Phage sensitivity. The phage sensitivity of each strain tested was determined by spotting phage lysates onto lawns of cells, prepared either by spreading $0.1 \mathrm{ml}$ of a late exponential culture onto EC-1.5\% agar or by adding $0.1 \mathrm{ml}$ cells to $2.5 \mathrm{ml}$ molten EC- $0.7 \%$ agar (overlay agar) and dispensing the suspension onto EC-1.5\% agar (bottom agar). Test plates were incubated for $24 \mathrm{~h}$ at $25^{\circ} \mathrm{C}$ and then scored for phage sensitivity. Lysis of mutant strains that are only weakly sensitive to phages is more easily observed when lawns are prepared using overlay agar than when cells are simply spread onto $1.5 \%$ agar plates. Cells of $C y$ tophaga (U67) were sensitive to 4 of the $43 C$. johnsonae phages ( $\phi \mathrm{Cj} 2, \phi \mathrm{Cj} 14, \phi \mathrm{Cj} 45$ and $\phi \mathrm{Cj} 47)$ when tested in overlay plates. Consequently, the sensitivities of motility mutants derived from Cytophaga (U67) to these four phages were determined. 
(iv) Adhesion assay. Cells were grown in broth to late exponential phase as determined by Klett reading, harvested by centrifugation at $10000 \mathrm{~g}$ for $10 \mathrm{~min}$, washed once in $\mathrm{PB}$, pelleted and resuspended in PB to a Klett reading $\left(\mathrm{K}_{\mathrm{i}}\right)$ of approximately 50 . A $25 \mathrm{ml}$ sample of this cell suspension was placed in an Erlenmeyer flask which contained $1 \mathrm{~g}$ shredded cheesecloth and was incubated at $23^{\circ} \mathrm{C}$ on a rotary shaker (175 r.p.m.). The final Klett reading $\left(K_{f}\right)$ of the broth (without cheesecloth) was determined after 10 min incubation. An adhesion index (AI) was determined by the relationship $A I=\left(K_{i}-K_{f}\right) / K_{i}$. Thus an AI value of 0.0 indicates no adhesion of cells to cheesecloth and an $\mathrm{AI}$ value of 1.0 indicates adherence of virtually all cells to cheesecloth.

(v) Determination of cell surface hydrophobicity by adherence to hexadecane. This technique is a modification of that developed by Rosenberg et al. (1980) and reviewed by Rosenberg (1984). Exponentially growing cells were harvested by centrifugation ( $10000 \mathrm{~g}$ for $10 \mathrm{~min}$ ), washed once in PB, pelleted again, and resuspended in PB. A sample of the cell suspension was placed into an acid-washed test tube and the optical density of the cell suspension was adjusted to give an $\mathrm{OD}_{535}\left(O D_{i}\right)$ of approximately 0.6 using a Spectronic 20 spectrophotometer. Hexadecane $(1 \mathrm{ml})$ was layered onto $3 \mathrm{ml}$ of the cell suspension in the acid-washed test tube and the suspension was vortexed vigorously for $1 \mathrm{~min}$. Following phase separation, the $\mathrm{OD}_{535}\left(\mathrm{OD}_{\mathrm{f}}\right)$ of the aqueous phase was determined. $A$ hydrophobicity index $(\mathrm{HI})$ was calculated using the relationship $\mathrm{HI}=\left(\mathrm{OD}_{\mathrm{i}}-\mathrm{OD}_{\mathrm{f}}\right) / \mathrm{OD}_{\mathrm{i}}$. Thus, HI values approaching $l$ indicate cells with very hydrophobic cell surfaces and $\mathrm{HI}$ values approaching 0 indicate cells with very hydrophilic cell surfaces.

(vi) Chitin digestion. Suspensions of cells were spotted on chitin plates, incubated at $25^{\circ} \mathrm{C}$ in humid chambers, and examined periodically over a 3 week period. Chitin digestion was determined by clearing of the turbid chitincontaining agar.

Estimation of TNM mutant frequency. Cells of a streptomycin-resistant (Str $\left.{ }^{\mathrm{r}}\right) \mathrm{TNM}$ strain of $C$. johnsonae (strain UW102349) were added to a suspension of wild-type cells at a ratio of $5: 10^{6}$ or $5: 10^{5}$ (Strr cells : wild-type cells). This mixed cell suspension was processed through an hexadecane extraction series and the $\mathrm{H} 1$ population of cells was diluted and plated onto EC-1.5\% agar. After $2 \mathrm{~d}$ incubation at $25^{\circ} \mathrm{C}$, colonies were counted to determine the total cell count and total number of nonspreading mutants in the selected population. Colonies were then replicated onto EC-1.5\% agar containing streptomycin $\left(100 \mu \mathrm{g} \mathrm{ml}^{-1}\right)$ to determine the percentage recovery of Str TNM mutants initially added to the population of cells. Assuming that the efficiency of recovery of spontaneous TNM mutants is the same as that of the seeded TNM mutants, an approximate mutant frequency for TNM mutants can be calculated using the following relationship: $M_{\mathrm{f}}=\left[\left(N_{\mathrm{n}}-N_{\mathrm{ns}}\right) / N_{\mathrm{t}}\right] \times 100 / R$, where $M_{\mathrm{f}}$ is the mutant frequency, $N_{\mathrm{n}}$ is the number of TNM mutants recovered, $N_{\mathrm{ns}}$ is the number of Str $^{\mathrm{r}}$ TNM mutants recovered, $N_{\mathrm{t}}$ is the total number of cells in the unselected population and $R$ is the percentage recovery of $\operatorname{Str}^{\mathrm{r}} \mathrm{TNM}$ mutants.

\section{RESULTS}

\section{Isolation of nonspreading mutants of $C$. johnsonae}

Nonspreading colonies (Fig. $1 c-f$ ) arising when selected populations were plated onto EC$1.5 \%$ agar and incubated at $25^{\circ} \mathrm{C}$ for $48 \mathrm{~h}$ were easily distinguished from the spreading colonies produced by wild-type cells (Fig. $1 a, b$ ). Furthermore, by examining the edges of nonspreading colonies by phase-contrast microscopy, colonies of TNM or MNS mutants (Fig. 1c, $d$ ) were easily distinguished from those of CNS mutants (Fig. 1e, $f$ ). The edges of colonies of CNS mutants displayed slender projections whereas those of MNS and TNM mutants were smooth. Although final designation of a mutant as TNM, MNS or CNS requires its isolation and characterization, inspection of colony edges as described above allows a reliable estimate to be made of the proportion of nonspreading mutants in a selected population represented by CNS mutants and by those that are either TNM or MNS.

Nonspreading mutants of $C$. johnsonae were easily isolated from populations selected by the cheesecloth method (Table 2). Only one or two passages through cheesecloth selection flasks were required to select for nonspreading mutants. Continued cycles increased the proportion of nonspreading mutants in the population, and the predominant type of mutant shifted from CNS to TNM/MNS with increased number of cycles.

Three additional nonspreading mutants (1 MNS, 1 TNM and 1CNS) were isolated using shredded tissue paper, glasswool or chitin, each of which was used in only one selection series. A greater number of cycles through selection flasks was required ( 3 with tissue paper, 4 with glasswool, and 10 with chitin) before any nonspreading mutants in the selected populations were identified. 

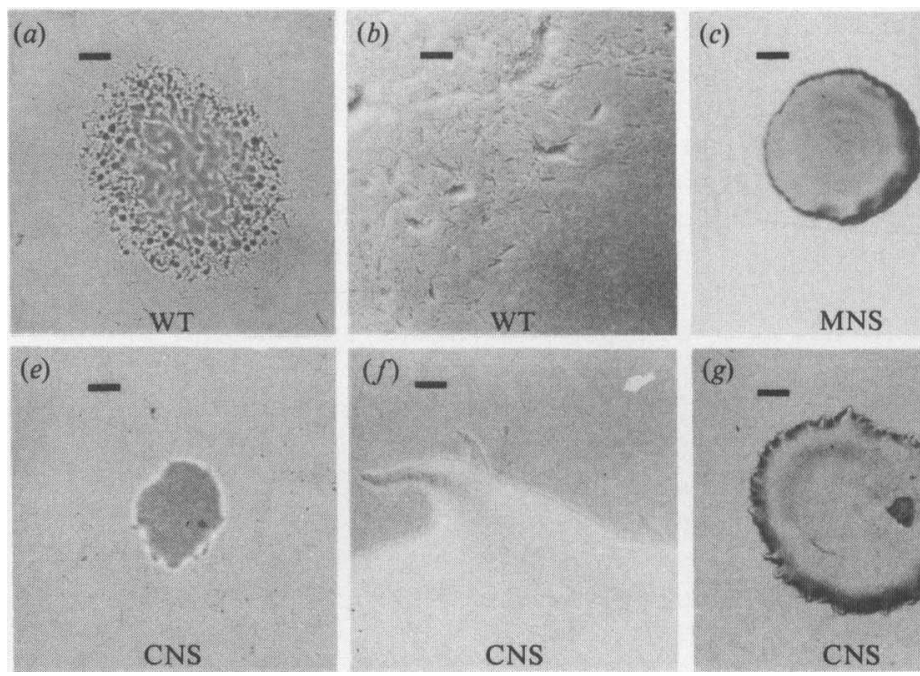

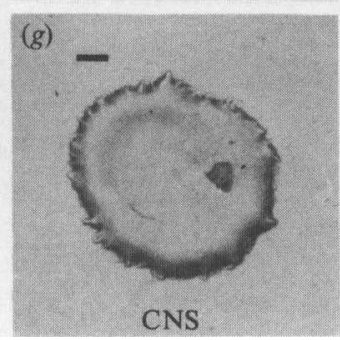

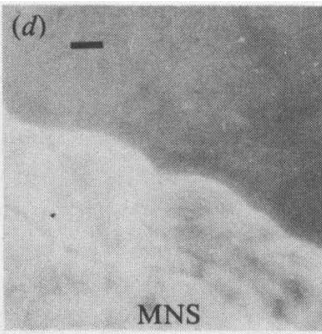

(h)

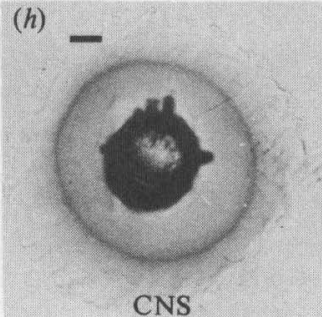

Fig. 1. Colonies and colony edges of wild-type cells and motility mutants of $C$. johnsonae. (a-f) Each colony was grown from a single cell incubated on EC-1.5\% agar for $48 \mathrm{~h}$ at $25^{\circ} \mathrm{C}$. (a) Strain UW 101 (wild-type, WT); bar, $4 \mathrm{~mm}$. (b) Edge of colony shown in (a); bar, $33 \mu \mathrm{m}$. (c) Strain UW1021 (MNS); bar, $0.8 \mathrm{~mm}$. Colonies produced by TNM mutants are identical with this one in appearance. (d) Edge of colony shown in $(c)$. The colony is light against a dark background; bar, $33 \mu \mathrm{m}$. (e) Strain UW1025 (CNS); bar, $1.6 \mathrm{~mm}$. ( $f$ ) Edge of colony shown in $(e)$; bar, $33 \mu \mathrm{m}$. $(\mathrm{g}, h)$ Colonies grown from spots of strain UW 1025 cells (approximately $3 \times 10^{6}$ cells per spot) on EC agar, incubated at $25^{\circ} \mathrm{C}$ for $24 \mathrm{~h} .(\mathrm{g})$ EC- $1.5 \%$ agar; $(h)$ EC- $0.7 \%$ agar (dark spot in centre was caused by deformation of agar with multipoint inoculator); bars, $1.6 \mathrm{~mm}$.

\section{Table 2. Types of nonspreading mutants of $C$. johnsonae selected using cheesecloth or hexadecane}

The bacterial population was either transferred $1-2,6$ or 12 times through cheesecloth selection flasks or extracted with hexadecane once $(\mathrm{H} 1)$ or twice $(\mathrm{H} 2)$. Details are given in Methods. The numbers of experiments are given in parentheses. For cheesecloth approximately 150 colonies were surveyed per selected population. For hexadecane approximately 1000 colonies were surveyed.

\begin{tabular}{|c|c|c|c|c|c|c|c|}
\hline \multirow[b]{2}{*}{ Cycle } & \multirow{2}{*}{$\begin{array}{c}\text { Percentage } \\
\text { total as } \\
\text { nonspreading }\end{array}$} & \multicolumn{2}{|c|}{$\begin{array}{l}\text { Nonspreading } \\
\text { colony types* }\end{array}$} & \multirow{2}{*}{$\begin{array}{l}\text { Total nonspreading } \\
\text { mutants isolated }\end{array}$} & \multicolumn{3}{|c|}{$\begin{array}{c}\text { Phenotypes of } \\
\text { isolatest }\end{array}$} \\
\hline & & CNS & TNM/MNS & & CNS & MNS & TN \\
\hline $\begin{array}{l}\text { heesecloth } \\
1-2(17) \\
6(7) \\
12(1)\end{array}$ & $\begin{array}{r}<2 \\
>90 \\
100\end{array}$ & $\begin{array}{r}>80 \\
<15 \\
0\end{array}$ & $\begin{array}{r}>85 \\
100\end{array}$ & $\begin{array}{c}17 \\
7 \\
0 \ddagger\end{array}$ & $\begin{array}{r}15 \\
0 \\
0\end{array}$ & $\begin{array}{l}2 \\
2 \\
0\end{array}$ & $\begin{array}{l}0 \\
5 \\
0\end{array}$ \\
\hline $\begin{array}{l}\text { Hexadeca } \\
\text { H1 (5) } \\
\text { H2 (2) }\end{array}$ & $\begin{array}{r}<2 \S \\
>55 \|\end{array}$ & $\begin{array}{l}<6 \\
<6\end{array}$ & $\begin{array}{l}>94 \\
>94\end{array}$ & $\begin{array}{l}6 \\
1\end{array}$ & $\begin{array}{l}1 \\
0\end{array}$ & $\begin{array}{l}1 \\
0\end{array}$ & $\begin{array}{l}4 \\
1\end{array}$ \\
\hline
\end{tabular}

* Based on microscopic observation of colony edges (see Fig. 1). See Table 1 for abbreviations.

$\dagger$ Based on characterization of isolates.

¥ No mutants were isolated after 12 transfers since mutants had been isolated from previous selection flasks in this series.

$\S$ Approximately $0.001 \%$ of the cells in the original population $\left(2 \times 10^{9}\right.$ cells $\left.\mathrm{ml}^{-1}\right)$ remained in the aqueous phase upon completion of an $\mathrm{H} 1$ series.

II Approximately $0.1 \%$ of the cells in the original population $\left(2 \times 10^{9}\right.$ cells $\left.\mathrm{ml}^{-1}\right)$ remained in the aqueous phase upon completion of an $\mathrm{H} 2$ series. 
Seven nonspreading mutants were isolated from populations of cells selected using hexadecane. The proportion of nonspreading mutants in selected populations increased from about $1 \%$ in $\mathrm{H} 1$ populations to about $60 \%$ in $\mathrm{H} 2$ populations, and the TNM/MNS type of mutant was predominant in both $\mathrm{H} 1$ and $\mathrm{H} 2$ (Table 2).

An estimate of the spontaneous mutant frequency of the TNM phenotype was determined by seeding populations of wild-type cells with cells of a Str ${ }^{r}$ TNM mutant and subjecting the mixed population to a single cycle of the hexadecane selection. In three separate experiments between $1.5 \times 10^{3}$ and $2.3 \times 10^{4} \mathrm{Str}^{\mathrm{r}} \mathrm{TNM}$ mutants were added to approximately $1.1 \times 10^{9}$ wild-type cells. Upon completion of the selection procedures, the resulting three $\mathrm{H} 1$ populations contained from $2.2 \times 10^{3}$ to $2.8 \times 10^{3}$ nonspreading mutants as determined from colony counts on EC$1.5 \%$ agar. All nonspreading colonies were typical of TNM/MNS mutants. In the three experiments, the number of $\mathrm{Str}^{r}$ mutants recovered ranged from $4.0 \times 10^{2}$ to $1.0 \times 10^{3}$, giving percentage recoveries of the $\operatorname{Str}^{r}$ TNM mutants ranging from $4 \cdot 3$ to $32 \cdot 0$, and corresponding mutant frequencies ranging from $5.0 \times 10^{-6}$ to $2.3 \times 10^{-5}$ (a mean value of $1.2 \times 10^{-5}$ ). However, since only three of four mutants isolated by picking TNM/MNS-type colonies from other $\mathrm{Hl}$ populations proved to be TNM, a better approximation of the mutant frequency to the TNM phenotype is $9.7 \times 10^{-6}$.

In another experiment, three nonspreading colonies were observed upon screening 6672 colonies arising from cells of an unselected population of wild-type cells (a mutant frequency of approximately $4.5 \times 10^{-4}$ ). All three colonies were typical of those of CNS mutants, and isolation and characterization of the three mutants confirmed the CNS classification. These three colonies may have arisen from progeny of a single mutant, as only one broth culture was used in this experiment.

\section{Characterization of nonspreading mutants of $C$. johnsonae}

All 11 TNM mutants isolated from populations subjected to selection for nonadherence to cheesecloth or hexadecane exhibited an unusual pleiotropy: they were unable to move under any conditions tested, resistant to all $C$. johnsonae phages, and incapable of chitin digestion. A total of 25 TNM mutants was tested for hydrophobicity and adherence. These mutants included the 11 isolated during this study and 14 TNM mutants randomly chosen from a large collection of such mutants isolated by phage selection or by screening colonies of mutagenized cells (Chang et al., 1984). All 25 TNM mutants tested were clearly distinguished from wild-type cells by their markedly reduced hydrophobicity and decreased adherence to cheesecloth (Table 3 ). Furthermore, unlike wild-type cells which adhered to hexadecane droplets along the entire length of their cells, no cells of TNM mutants were observed to adhere to hexadecane.

The 20 CNS mutants selected on the basis of nonadherence were sensitive to some or all $C$. johnsonae phages and all digested chitin. With one exception (strain UW102299), CNS mutants did not differ from wild-type cells in adherence to cheesecloth or in cell surface hydrophobicity (Table 3). Cells of strain UW102299 were less hydrophobic than wild-type cells, but showed no decreased adherence to cheesecloth.

All six MNS isolates obtained in this study digested chitin, and four of the six were sensitive to some or all $C$. johnsonae phages tested. Two MNS mutants (UW1022 and UW 1023) resembled TNM mutants in being resistant to all phages. Eight MNS mutants were assayed for cell surface hydrophobicity and adherence to cheesecloth (Table 3). Of the eight, three (UW 1024, UW 10243 and UW102150) behaved as wild-type cells in both assays. One strain (UW1021) exhibited an increased cell surface hydrophobicity (HI of 0.56$)$, but its AI value was close to that of wild-type cells. The four other MNS strains exhibited markedly decreased AI and HI values.

\section{Isolation and characterization of nonspreading mutants of other gliding bacteria}

The cheesecloth method was used successfully to select nonadherent, nonspreading mutants of four other species of gliding bacteria (mutants are listed in Table 1), but the efficacy of the method varied among these species (Table 4). In all cases except with $M$. xanthus, it was possible to obtain selected populations in which nonspreading mutants made up at least $80 \%$ of the total. 
Table 3. Adhesive and hydrophobic properties of nonspreading mutants and wild-type cells of $C$. johnsonae

For the hydrophobicity index (HI) values approaching 1 indicate cells with very hydrophobic cell surfaces and values approaching 0 indicate cells with hydrophilic cell surfaces. Except for wild-type cells the ranges of the means for individual strains within the indicated phenotypes are given. At least three measurements were made per strain and the SD was never greater than 0.14 for any individual strain. For the adhesion index, values approaching 1 indicate adhesion of virtually all cells to cheesecloth and values approaching 0 indicate no adhesion of cells to cheesecloth. Except for wild-type cells the ranges of the means for individual strains within the indicated phenotypes are given. At least three measurements were made per strain and the SD was never greater than $0 \cdot 15$.

$\begin{array}{cccc}\text { Phenotype* }^{*} & \begin{array}{c}\text { No. of } \\ \text { strains } \\ \text { tested }\end{array} & \begin{array}{c}\text { Hydrophobicity } \\ \text { index }\end{array} & \begin{array}{c}\text { Adhesion } \\ \text { index }\end{array} \\ \text { W } & 1 & 0.38 & 0.79 \\ \text { CNS } & 20 & 0 \cdot 20-0.45 \dagger & 0.74-0.85 \\ \text { MNS } & 8 \ddagger & 0.04-0.45 & 0.05-0.70 \\ \text { TNM } & 25 \S & 0.01-0.11 & 0.01-0.07\end{array}$

* See Table 1 for abbreviations.

† Except for strain UW102299 (HI of 0.20) the HI of all other CNS mutants ranged from 0.30 to 0.45.

$¥$ Six strains from this study; two isolated previously (Chang et al., 1984).

$\S 11$ strains from this study; 14 isolated previously (Chang et al., 1984).

Table 4. Effectiveness of the cheesecloth method for selecting nonspreading mutants of different gliding bacteria

In general, after $1,2,6,8,10,12,16$ and 20 transfers, populations of cells were diluted and plated in triplicate to give rise to approximately 50 colonies per plate. Where appropriate the range of values is indicated. Numbers of experiments are indicated in parentheses.

\begin{tabular}{lcc}
\multicolumn{1}{c}{$\begin{array}{c}\text { No. of transfers through selection flasks } \\
\text { before populations consisted of : }\end{array}$} \\
$\begin{array}{c}\text { At least } 0.7 \% \text { of total } \\
\text { as non-spreading mutants }\end{array}$ & $\begin{array}{c}\text { At least } 80 \% \text { of total } \\
\text { as non-spreading mutants }\end{array}$ \\
C. johnsonae UW101 & $1-2(17)$ & $6(7)$ \\
Cytophaga (U67) & $4-12(5)$ & $16-20(4)$ \\
F. columnaris 1R43 & $6-10(5)$ & $16-20(3)$ \\
Flexibacter (FS-1) & $1-2(9)$ & $6-8(6)$
\end{tabular}

In only two of eight attempts were any nonspreading mutants of $M$. xanthus isolated, and in only one of these did mutants comprise as much as $5 \%$ of the selected population, and 20 cycles were required for this.

Cells of all strains [Cytophaga (U67), Flexibacter (FS-1) and F. columnaris] that adhered to hexadecane did so along their entire length. Nonspreading mutants of Cytophaga (U67) and Flexibacter (FS-1) were isolated using the hexadecane procedure. Starting with approximately $2 \times 10^{9}$ viable cells, the total number of viable cells remaining in $\mathrm{H} 1$ populations ranged from $10^{3}$ to $10^{5}$ with both Cytophaga (U67) and Flexibacter (FS-1). Fewer than $2 \%$ of the cells in these $\mathrm{H} 1$ populations gave rise to nonspreading colonies, and the proportion of nonspreading mutants in $\mathrm{H} 2$ populations was always greater than that observed in $\mathrm{H} 1$ populations (Table 5). The method was as effective with Flexibacter (FS-1) as with $C$. johnsonae, but was less effective with Cytophaga (U67). Eight attempts to isolate nonspreading mutants of $M$. xanthus or $F$. columnaris using the hexadecane procedure were unsucessful. In the case of $F$. columnaris, hexadecane extractions appeared to be harmful to the cells, sometimes causing lysis. With $M$. xanthus, adherence of cells to hexadecane was minimal, with approximately $50 \%$ of the initial populations of cells remaining in the $\mathrm{H} 1$ populations. 
Table 5. Effectiveness of hexadecane for selecting nonspreading mutants of different gliding bacteria

Approximately 1000 colonies were surveyed per selected population. When more than one experiment was done the range of values is indicated. Numbers of experiments are indicated in parentheses. $\mathrm{Hl}$, population plated out after a single selection series ( 15 serial extractions with hexadecane); $\mathrm{H} 2$, cells from $\mathrm{Hl}$ were inoculated into fresh broth, incubated until late exponential phase and processed through a second selection series; $\mathrm{H} 3$, cells from $\mathrm{H} 2$ were inoculated into fresh broth, incubated until late exponential phase and processed through a third selection series; ND, not determined.

\begin{tabular}{lrrr} 
& \multicolumn{1}{c}{$\begin{array}{c}\text { Percentage of total colonies } \\
\text { which are nonspreading }\end{array}$} \\
\cline { 2 - 4 } Parental strain & \multicolumn{1}{c}{$\mathrm{H} 1$} & $\mathrm{H} 2$ & $\mathrm{H} 3$ \\
C. johnsonae UW 101 & $0.2-1.9(5)$ & $55-65(2)$ & $\mathrm{ND}$ \\
Cytophaga (U67) & $0-0.4(3)$ & $0.9-1.4(2)$ & $7.5(1)$ \\
F. columnaris 1R43 & $0(8)$ & $0(8)$ & $0(8)$ \\
Flexibacter (FS-1) & $0-1.5(3)$ & $44-67(2)$ & ND \\
M. xanthus DK 101 & $0(8)$ & $0(8)$ & $0(8)$
\end{tabular}

Table 6. Hydrophobicity of nonspreading mutants and wild-type cells of gliding bacteria

$\begin{array}{llcc}\text { Parental strain } & \text { Phenotype* } & \begin{array}{c}\text { No. of } \\ \text { isolates }\end{array} & \begin{array}{c}\text { Hydrophobicity } \\ \text { index } \dagger\end{array} \\ \text { Cytophaga (U67) } & \text { W } & 1 & 0 \cdot 22 \\ & \text { CNS } & 6 & 0 \cdot 10-0 \cdot 30 \\ & \text { MNS } & 1 & 0 \cdot 18 \\ & \text { TNM } & 2 & 0 \cdot 08-0 \cdot 29 \\ \text { F. columnaris 1R43 } & \text { W } & 1 & 0 \cdot 35 \\ & \text { CNS } & 5 & 0 \cdot 35-0 \cdot 40 \\ \text { Flexibacter (FS-1) } & \text { TNM } & 3 & 0 \cdot 33-0.41 \\ & \text { W } & 1 & 0 \cdot 58 \\ & \text { CNS } & 9 & 0 \cdot 20-0.71 \\ & \text { MNS } & 3 & 0 \cdot 18-0.48 \\ \text { M. xanthus } \text { DK 101 } & \text { TNM } & 1 & 0 \cdot 19 \\ & \text { W } & 1 & 0.01 \\ & \text { NS } & 2 & 0.01\end{array}$

* See Table 1 for abbreviations.

† Values approaching 1 indicate cells with very hydrophobic cell surfaces and values approaching 0 indicate cells with hydrophilic cell surfaces. Where more than one strain is listed, the values represent the range of the means for individual strains within each phenotype. At least three measurements were made per strain and the SD of an individual strain was never greater than $0 \cdot 14$.

As with $C$. johnsonae, mutants of Cytophaga (U67), $F$. columnaris and Flexibacter (FS-1) were classified as CNS, MNS or TNM (Table 1). To determine if TNM mutants of any of these displayed a pleiotropy similar to that observed in TNM mutants of $C$. johnsonae, we tested the hydrophobicity of nonspreading mutants of Cytophaga (U67), Flexibacter (FS-1), F. columnaris and $M$. xanthus. The phage sensitivity of nonspreading mutants of $C y t o p h a g a$ (U67) and the ability of nonspreading mutants of Flexibacter (FS-1) to digest chitin were also determined.

Both TNM mutants of Cytophaga (U67) were resistant to all four phages that infect wild-type cells, whereas all CNS mutants were sensitive. Strain UW10610, the only MNS mutant of Cytophaga (U67) isolated, was resistant to $\phi \mathrm{Cj} 2, \phi \mathrm{Cj} 14$ and $\phi \mathrm{Cj} 47$ and sensitive to $\phi \mathrm{Cj} 45$. An additional 11 TNM mutants were isolated by phage selection of strain $\mathrm{U} 67$ and all were resistant to all four phages.

Wild-type cells of Flexibacter (FS-1) were previously reported to digest chitin (Christensen, 1977). When incubated on chitin plates, all MNS and CNS mutants of strain FS-1 degraded chitin as rapidly as did wild-type cells (broad zones of clearing within $2 \mathrm{~d}$ of incubation), but the one TNM mutant derived from this strain produced only slight clearing after 2 weeks incubation. Longer incubation did not result in further degradation of chitin. 
The hydrophobicity of nonspreading mutants and wild-type cells of Cytophaga (U67), Flexibacter (FS-1), F. columnaris and M. xanthus was determined (Table 6). Nonspreading mutants of $F$. columnaris and $M$. xanthus did not differ from their parental strains in cell surface hydrophobicity. Wild-type cells and those of some nonspreading mutants of Cytophaga (U67) sometimes caused emulsification of the hexadecane, possibly interfering with the assay. Therefore, differences in hydrophobicity may exist between wild-type cells and mutants, although none were detected. The one TNM mutant of Flexibacter (FS-1) was markedly more hydrophilic than cells of its parental strain, and large differences in hydrophobicity existed among CNS and MNS mutants of this strain. Unlike wild-type cells, the one TNM mutant of Flexibacter (FS-1) did not form filaments.

Cells of the TNM mutant of strain FS-1 adhered to cheesecloth slightly less than wild-type cells (AI of 0.74 compared with 0.85 ). There were no differences in adherence among the three TNM mutants of $F$. columnaris and the wild-type strain. Eight of the 11 TNM mutants isolated from Cytophaga (U67) by phage selection and both TNM mutants obtained by the hexadecane method differed markedly from wild-type cells (AI of 0.00 to 0.15 for mutants; 0.36 for wild-type). The other three mutants obtained by phage selection of strain U67 did not differ from wild-type cells in adherence. These three mutants were classified as TNM because no movement of their cells was detected in wet mounts, but their ability to adhere to cheesecloth separates them from the other TNM mutants. Perhaps they are capable of slight movements which are not detectable by microscopy.

\section{DISCUSSION}

The two selection procedures reported here have been used before to isolate nonadherent mutants (Umbreit \& Pate, 1978) or less hydrophobic mutants (Ofek et al., 1983; Rosenberg, 1984; Rosenberg \& Rosenberg, 1981; Tylewska et al., 1979) of various bacteria and were here successfully adapted to isolate motility mutants of gliding bacteria. The success of these methods fulfils the predictions made regarding surface properties of motility mutants of $C$. johnsonae. These predictions were based on a model, which was the result of attempts to explain characteristics of previously isolated TNM, MNS and CNS mutants (Chang et al., 1984), and on the inhibitory effects of sugars on translocation of motile cells of $C$. johnsonae (Wolkin \& Pate, 1984). The success of the selection procedures lends support to the model, since it would not otherwise have been predicted that motility mutants could be isolated by selecting for nonadherent or less hydrophobic cells.

The conditions used in mutant selections and in assays for adherence of hydrophobicity were those found to be optimal for use with $C$. johnsonae, and no effort was made to determine optimal conditions for use with the other four strains tested. Nevertheless, one or both of the two selection procedures proved successful to varying degrees with all strains, suggesting that the methods will be broadly useful for isolating nonspreading mutants of gliding bacteria. Parameters that were found to be important here (data not shown), and that must be varied to determine optimal conditions of the methods when adapted to other strains, include the nature of the suspending buffers, relative volumes of the two solutes in the biphasic systems, growth conditions, and stage of growth at which cells are transferred in the cheesecloth method or harvested for use in the hexadecane method.

Using $C$. johnsonae, CNS mutants predominate among nonspreading isolates from selected populations obtained after one or two passages through cheesecloth selection flasks, and TNM/MNS mutants predominate after continued cycles through cheesecloth selections and also in selected populations obtained by the hexadecane method. Apparently, since CNS mutants occur at a higher frequency than do TNM mutants (about $10^{-4}$ versus $10^{-6}$ ), they appear early in the cheesecloth selection. But TNM mutants predominate upon continued selection because their ability to attach is severely limited. An unexplained result of the adhesion assays is that most CNS mutants adhere to cheesecloth as well as or better than wild-type cells, even though some of them were isolated by the cheesecloth technique. Two possible reasons for this are (i) wild-type cells attach better than CNS mutants under selection conditions but not 
under assay conditions, or (ii) the assay may not be sufficiently sensitive to detect slight differences in adherence between CNS mutants and wild-type cells.

The mutants of $C$. johnsonae described here fell into the three general classes (TNM, CNS, MNS) to which most motility mutants of this organism obtained by other methods have been assigned (Chang et al., 1984). All TNM mutants isolated by the new procedures exhibited the same pleiotropy observed in previously isolated mutants of this class. The work reported here adds two more characteristics to the list of properties found to be altered in TNM mutants: decreased adherence to cheesecloth and decreased cell surface hydrophobicity. Thus, all TNM mutants tested, whether isolated by screening mutagenized cells (Chang $e t$ al., 1984), by phage selection (Chang et al., 1984; Pate et al., 1979), or by hexadecane or cheesecloth methods, are invariably nonmotile, phage resistant, unable to digest chitin, nonadherent, and nonhydrophobic.

It was suggested earlier (Chang et al., 1984; Wolkin \& Pate, 1984) that the TNM pleiotropy reflects alteration of several surface properties that occurs as a consequence of converting a moving surface slime to a static slime enveloping nonmotile cells, and that this condition always results when cells become nonmotile. The alternative explanation, that a mutation directly affecting one of the other characteristics associated with the pleiotropy always results in nonmotile cells is unlikely, since mutants are available that are altered in certain single properties associated with the pleiotropy but are motile and are not pleiotropic. Phage resistance (Chang et al., 1984; Wolkin \& Pate, 1984), hydrophilicity and decreased adherence to cheesecloth are conditions that do not invariably lead to the inability to move, but the inability to move invariably results in these conditions.

Based on cell movement and colony spread, the same classes of nonspreading mutants isolated using $C$. johnsonae were selected by both methods using Cytophaga (U67) and Flexibacter (FS-1) and only by the cheesecloth method using $F$. columnaris. This system of classification cannot be applied to mutants of $M$. xanthus. Preliminary results indicate that TNM mutants derived from Cytophaga (U67) and Flexibacter (FS-1) exhibit a pleiotropy similar to that of TNM mutants of $C$. johnsonae. Too few characteristics are available for testing TNM mutants of $F$. columnaris to see if they too are pleiotropic. Previous studies (Hodgkin \& Kaiser, 1979 $a, b$ ) of nonspreading mutants of $M$. xanthus indicate that a similar pleiotropy is not associated with the nonmotile condition in this organism. Moreover, of the five strains we studied, the selection procedures were least effective with $M$. xanthus: no selection with the hexadecane method and only slight selection with the cheesecloth method. The extremely low efficacy of the cheesecloth method when applied to $M$. xanthus raises the possibility that the procedure provides no selection for nonspreading mutants and that those few that were isolated were due to unexpectedly high mutation frequencies in those cultures, similar to the unexplained appearance of large numbers of nonspreading mutants in certain cultures of $M$. xanthus reported by Burchard (1974). Perhaps the TNM pleiotropy will prove to be associated only with nonmotile mutants derived from relatively fast gliding bacteria on whose surfaces movement of latex microspheres can be demonstrated. Microsphere movements of the kinds reported with cells of $C$. johnsonae and $F$. columnaris (Pate \& Chang, 1979) and with Cytophaga (U67) (Lapidus \& Berg, 1982) were observed in this study with cells of Flexibacter (FS-1) (data not shown), but similar kinds of movements were not seen with cells of $M$. xanthus (Dworkin et al., 1983).

The cellular components altered in nonadherent, nonspreading mutants are unknown. Cellular components of other bacteria involved in nonspecific adhesion to various surfaces and to hydrocarbons include slimes, capsules, the M-protein and small fibrils found on the surfaces of some bacteria (Ofek et al., 1983; Pines \& Gutnick, 1984; Rosenberg, 1984). Filaments of the cyanobacterium Phormidium sp. (Fattom \& Shilo, 1984) and cells of $C$. johnsonae, Cytophaga (U67), Flexibacter (FS-1) and F. columnaris (this study) all adhered to hexadecane droplets along the lengths of their cells, indicating distribution of hydrophobic sites over the entire cell. But cells of Flexibacter sp. strain BH3 were reported to adhere to hydrocarbons via their cell poles, suggesting localization of hydrophobic sites in these regions (Marshall \& Cruickshank, 1973). Simon (1981) reported that a nonmotile mutant derived from the gliding cyanobacterium Aphanothece halophytica lacked a high molecular weight glycoprotein that is present in wild-type 
cell wall fractions. Further examination of this mutant (R. D. Simon, personal communication) revealed differences between the mutant and wild-type cells in cell envelope structures (electron microscopy of thin-sectional cells) and in hydrophobicity. This report of a correlation between hydrophobicity and gliding in a cyanobacterium is intriguing in view of our findings with Cytophaga and Flexibacter species. Recently, Kupfer \& Zusman (1984) reported differences in hydrophobicity of cells of $M$. xanthus at different stages during the developmental cycle.

Differences in the patterns of movement of microspheres on cells of $C$. johnsonae and Cytophaga (U67) led to two different proposals for the basis of gliding motility (Lapidus \& Berg, 1982; Pate \& Chang, 1979). The mechanisms underlying gliding may actually differ in these two organisms, or the different patterns of microsphere movement may be due to minor differences associated with the same kind of motility apparatus in the two strains. Whatever the nature of the molecular machinery underlying gliding eventually proves to be, the evidence presented here strongly suggests that the mechanisms are the same in these two strains. Although strain U67 does not digest chitin, its relatedness to $C$. johnsonae is suggested by its sensitivity to some $C$. johnsonae phages and by similarities of TNM mutants derived from the two strains: in both cases, the inability to move is associated with phage resistance and decreased adherence to cheesecloth. Strains that share these unusual characteristics must be closely related and have probably not evolved different mechanisms of gliding. In fact, four of the five strains of gliders studied here are likely to possess the same basic mechanism of motility, based on the following evidence: (i) latex microspheres are moved about on the surfaces of all four strains [C. johnsonae, $F$. columnaris, Cytophaga (U67) and Flexibacter (FS-1)]; (ii) one or both of the procedures described here are very effective for isolation of motility mutants of all four strains; (iii) based on a limited survey, becoming nonmotile leads to a similar pleiotropy in at least three of the four strains.

This research was supported by the College of Agricultural and Life Sciences, University of Wisconsin, Madison, Wis., USA, and by grant PCM-8316426 from the National Science Foundation. We thank Mel Rosenberg of Tel Aviv University, Israel, for helpful correspondence concerning bacterial adherence to hydrocarbons.

\section{REFERENCES}

BURCHARD, R. P. (1970). Gliding motility mutants of Myxococcus xanthus. Journal of Bacteriology 104, 940-947.

BURCHARD, R. P. (1974). Studies on gliding motility in Myxoccus xanthus. Archives of Microbiology 99, 271280.

Chang, L.-Y. E. (1982). Studies on gliding motility in Cytophaga johnsonae. PhD thesis, University of Wisconsin, Madison, USA.

Chang, L.-Y. E. \& Pate, J. L. (1981). Nutritional requirements of Cytophaga johnsonae and some of its auxotrophic mutants. Current Microbiology 5, 235240.

Chang, L.-Y. E., Pate, J. L. \& Betzig, R. J. (1984). Isolation and characterization of nonspreading mutants of the gliding bacterium Cytophaga johnsonae. Journal of Bacteriology 159, 26-35.

Christensen, P. J. (1977). The history, biology and taxonomy of the Cytophaga group. Canadian Journal of Microbiology 23, 1599-1653.

DAYRELl-HaRT, B. \& Burchard, R. P. (1979). Association of flexing and gliding in Flexibacter. Journal of Bacteriology 132, 1417-1420.

DWORKIN, M., KeLler, K. H. \& WeISBERG, D. (1983). Experimental observations consistent with a surface tension model of gliding motility of Myxococcus xanthus. Journal of Bacteriology 155, 1367-1371.
Fatrom, A. \& Shilo, M. (1984). Hydrophobicity as an adhesion mechanism in benthic cyanobacteria. Applied and Environmental Microbiology 47, 135-143.

Glaser, J. \& Pate, J. L. (1973). Isolation and characterization of gliding motility mutants of Cytophaga columnaris. Archiv für Mikrobiologie 93, 295-309.

HENRICKSEN, J. (1972). Bacterial surface translocation: a survey and a classification. Bacteriological Reviews 36, 478-503.

HoDGKIN, J. \& KaISER, D. (1977). Cell-to-cell stimulation of movement in nonmotile mutants of $M$ yxococcus. Proceedings of the National Academy of Sciences of the United States of America 74, 2938-2942.

HODGKIN, J. \& KAISER, D. (1979a). Genetics of gliding motility in Myxococcus xanthus (Myxobacterales): genes controlling movement of single cells. Molecular and General Genetics 171, 167-176.

HODGKIN, J. \& KAISER, D. (1979b). Genetics of gliding motility in Myxococcus xanthus (Myxobacterales): two gene systems control movement. Molecular and General Genetics 171, 177-191.

KUPFER, D. \& ZUSMAN, D. R. (1984). Changes in cell surface hydrophobicity of Myxococcus xanthus are correlated with sporulation-related events in the developmental program. Journal of Bacteriology 159, 776-779. 
LAPIDUS, I. R. \& BERG, H. C. (1982). Gliding motility of Cytophaga sp. strain U67. Journal of Bacteriology 151, 384-398.

MACRAE, T. H. \& MCCuRdy, H. D. (1976). The isolation and characterization of gliding motility mutants of Myxococcus xanthus. Canadian Journal of Microbiology 22, 1589-1593.

Marshall, K. C. \& Cruickshank, R. H. (1973). Cell surface hydrophobicity and the orientation of certain bacteria at interfaces. Archives of Microbiology 91, 29-40.

OfEK, I., WhitNaCK, E. \& Beachey, E. H. (1983). Hydrophobic interactions of group A streptococci with hexadecane droplets. Journal of Bacteriology 154, 139-145.

Pate, J. L. \& Chang, L.-Y. E. (1979). Evidence that gliding motility in prokaryotic cells is driven by rotary assemblies in the cell envelopes. Current Microbiology 2, 59-64.

Pate, J. L., Petzold, S. J. \& Chang, L.-Y. E. (1979). Phages for the gliding bacterium Cytophaga johnsonae that infect only motile cells. Current Microbiology 2, 257-262.

Pines, O. \& GuTNICK, D. (1984). Alternate hydrophobic sites on the cell surface of Acinetobacter calcoaceticus RAG-1. FEMS Microbiological Letters 22, 307-311.

Rosenberg, M. (1984). Bacterial adherence to hydrocarbons: a useful technique for studying cell surface hydrophobicity. FEMS Microbiological Letters 22, 289-295.
Rosenberg, M. \& RosenberG, E. (1981). Role of adherence in growth of Acinetobacter calcoaceticus RAG-1 on hexadecane. Journal of Bacteriology 148, $51-57$.

Rosenberg, M., Gutnick, D. \& Rosenberg, E. (1980). Adherence of bacteria to hydrocarbons: a simple method for measuring cell-surface hydrophobicity. FEMS Microbiological Letters 9, 29-33.

Simon, G. D. \& White, D. (1971). Growth and morphological characteristics of a species of Flexibacter. Archiv für Mikrobiologie 78, 1-16.

SIMON, R. D. (1981). Gliding motility in Aphanothece halophytica: analysis of wall proteins in mot mutants. Journal of Bacteriology 148, 315-321.

Stanier, R. Y. (1946). Studies on nonfruiting myxobacteria. I. Cytophaga johnsonae, n. sp., a chitindecomposing myxobacterium. Journal of Bacteriology 53, 297-315.

TylewsKa, S. K. HJertén, S. \& Wadström, T. (1979). Contribution of $\mathrm{M}$-protein to the hydrophobic surface properties of Streptococcus pyogenes. FEMS Microbiological Letters 6, 249-253.

Umbreit, T. H. \& Pate, J. L. (1979). Characterization of the holdfast region of wild-type cells and holdfast mutants of Asticcacaulis biprosthecum. Archives of Microbiology 118, 157-168.

Wolkin, R. H. \& PATE, J. L. (1984). Translocation of motile cells of the gliding bacterium Cytophaga johnsonae depends on a surface component that may be modified by sugars. Journal of General Microbiology 130, 2651-2669. 